\title{
Hydrogeochemical assessment of groundwater quality for few habitations of Chandel District, Manipur (India)
}

\author{
Wazir Alam ${ }^{1} \cdot$ K. Sonamani Singh ${ }^{2} \cdot$ Yumnam Gyanendra ${ }^{1} \cdot$ Ranu J. Laishram ${ }^{1} \cdot$ Nashimun Nesa $^{1}$
}

Received: 11 February 2020 / Accepted: 17 April 2020 / Published online: 28 April 2020

(c) The Author(s) 2020

\begin{abstract}
A preliminary hydrogeochemical investigation of groundwater quality for spatially distributed habitations of Chandel district of Manipur was carried out with an objective to assess the suitability of groundwater for different anthropogenic uses. Altogether, eighteen (18) physico-chemical parameters including in situ parameters and major ions were analysed for classification and hydrogeochemical characterisation of groundwater resources of the study area. Some of the anions such as $\mathrm{Cl}^{-}$and $\mathrm{SO}_{4}{ }^{2-}$ were found in exceeding concentrations. Similarly, 23.1\% samples exceed fluoride $\left(\mathrm{F}^{-}\right)$concentration beyond the permissible limit of $1.5 \mathrm{mg} / \mathrm{l}$. The water quality index of the groundwater samples of the habitations was found to be influenced by the elevated concentrations of water quality parameters such as $\mathrm{F}^{-}$, EC, TDS, salinity, $\mathrm{Cl}^{-}$and $\mathrm{SO}_{4}{ }^{2-}$. The geochemical analysis reveals that the majority of geochemical facies of the groundwater samples are dominated by $\mathrm{Na}^{+}-\mathrm{Ca}^{2+}-\mathrm{Mg}^{2+}-\mathrm{Cl}^{-}-\mathrm{HCO}_{3}{ }^{-}-\mathrm{SO}_{4}{ }^{2-}$ type of water resulting from rock-weathering geochemical process. Bivariate and multivariate analysis indicates the influences of hydrogeochemical interactions in the aquifer on the overall water quality. The irrigational water quality indices demonstrate that the water qualities of most of the sources are within the acceptable range except for few samples with high salinity and alkali hazards.
\end{abstract}

Keywords Groundwater quality $\cdot$ Hydrogeochemistry $\cdot$ Water quality index $\cdot$ Fluoride $\cdot$ Salinity $\cdot$ Irrigation

\section{Introduction}

Groundwater is one of the most exploited fresh water resources across the world used for various anthropogenic purposes. Generally, groundwater quality and their uses are mainly determined by various factors such as condition of sub-surface environment, types of lithological formation, hydrogeochemical interactions within aquifer and various other anthropogenic factors (Todd 2003). The quality, accessibility and availability of groundwater play a crucial role in determining the quality of life and overall development of the people in a region (WHO 2011). Although arid and semiarid regions across the world are extensively depended on groundwater resources, growing water scarcity scenario and quality water deficit have led to exploitation of groundwater

Wazir Alam

wazir@manipuruniv.ac.in

1 Department of Forestry and Environmental Science, Manipur University (A Central University),

Canchipur, Imphal 795003, India

2 ICAR-KVK, Chandel, Manipur 795127, India resources in several parts of world including India (Verma et al. 2015, Mukherjee et al. 2011; Mahanta et al. 2009). In aquifer, groundwater exists as an electrolyte solution due to release of various geogenic ions from the aquifer matrix and their presence prominently determines the quality of groundwater (McSween et al. 2003). So, in order to safely access the trapped groundwater from the aquifer of a region, it is very much essential to ensure suitability of groundwater quality for public health safety (Kumar et al. 2009; Mukherjee et al. 2011). Due to the presence of geogenic contaminants such as arsenic, fluoride, uranium, heavy and trace elements in groundwater, a range of public health issues have been reported from various parts of the world (Bhattacharya et al. 2012). Similar incidents are also reported from many parts of the Indian states, particularly Ganga-Brahmaputra-Meghna (GBM) plain of India (Verma et al. 2015; Mahanta et al. 2015; Choudhury et al. 2011). Geologically, north-east (NE) India belongs to similar origin of Himalayan orogeny and lies within the catchment of Brahmaputra and Meghna basin, where problems of geogenic contamination of groundwater are extensively reported (Alam et al. 2019; Mukherjee et al. 2015; Chakraborty et al. 2008). So, 
the presence of geogenic contaminants in the groundwater resources of the region is quite apparent, and it is already revealed by a few preliminary research findings (Alam and Yumnam 2017; Devi et al. 2012; Chakraborty et al. 2008).

\section{Study area}

The groundwater samples were collected from thirty-three (33) spatially distributed habitations of Chandel district located in the south-eastern hilly landscape of Manipur, India (Fig. 1). The district spread over an area of 3313 sq. $\mathrm{km}$. having a sparsely distributed and scattered population of around 144,028 (Census 2011). The study area is situated in a peculiar physiographic location of Eastern Himalayas occupied by mostly north-south parallel hill ranges made up of consolidated and semi-consolidated rocks belonging to Pre-Mesozoic to Miocene age (CGWB 2013). The consolidated rock formations are confined towards the eastern landscape and boarder of Myanmar, while semi-consolidated formations cover almost the entire foothill and valley belonging to Disang, Barail, Surma and Tipam Group of rocks (Devi et al. 2012). Groundwater occurs in secondary porosity consisting of joints, fissures, fractures and weathered residuum of consolidated, semi-consolidated rocks and in inter-granular pore spaces. Springs are also one of the major sources of water supply in the region (CGWB 2013). The region experiences subtropical to temperate climate with temperature varying between 5 and $35{ }^{\circ} \mathrm{C}$ and receives sufficient annual average rainfall $(1036 \mathrm{~mm})$ mostly contributed from SW tropical monsoon during the month of May and August (MSAPCC 2015).

\section{Materials and methods}

\section{Sampling and in situ analysis}

Thirty-three (33) spatially distributed groundwater samples from selected habitations of Chandel district were collected, and in situ parameters such as temperature, $\mathrm{pH}$, electrical conductivity (EC), dissolved oxygen (DO), salinity, total dissolved solids (TDS) and oxidation reduction potential (ORP) were assessed using field test probes/sensors (Eutech/ Hanna). The samples were collected from wells, tube wells and springs analysed as per the protocols of APHA (2005). Tube wells/wells were sufficiently flushed before collecting samples, and preservation of the samples was carried out using $1 \% \mathrm{HNO}_{3}$ to maintain $\mathrm{pH}$ below 2 , for further laboratory analysis. Geographic coordinates of the sampling locations were recorded using Global Positioning System (GPS) (Garmin, eTrex 30) in order to mark the pinpoint locations.

\section{Laboratory analysis}

The collected and preserved samples were analysed in the laboratory for major parameters such as alkalinity, hardness, $\mathrm{Na}^{+}, \mathrm{Ca}^{2+}, \mathrm{K}^{+}, \mathrm{Mg}^{2+}, \mathrm{Cl}^{-}, \mathrm{F}^{-}, \mathrm{NO}_{3}{ }^{-}, \mathrm{SO}_{4}{ }^{2-}$ and $\mathrm{PO}_{4}{ }^{3-}$ using titrimetric, gravimetric and photometric methods as described in the standard procedures of APHA (2005). The concentration of fluoride $\left(\mathrm{F}^{-}\right)$was determined
Fig. 1 Map shows the sampling locations of the study area
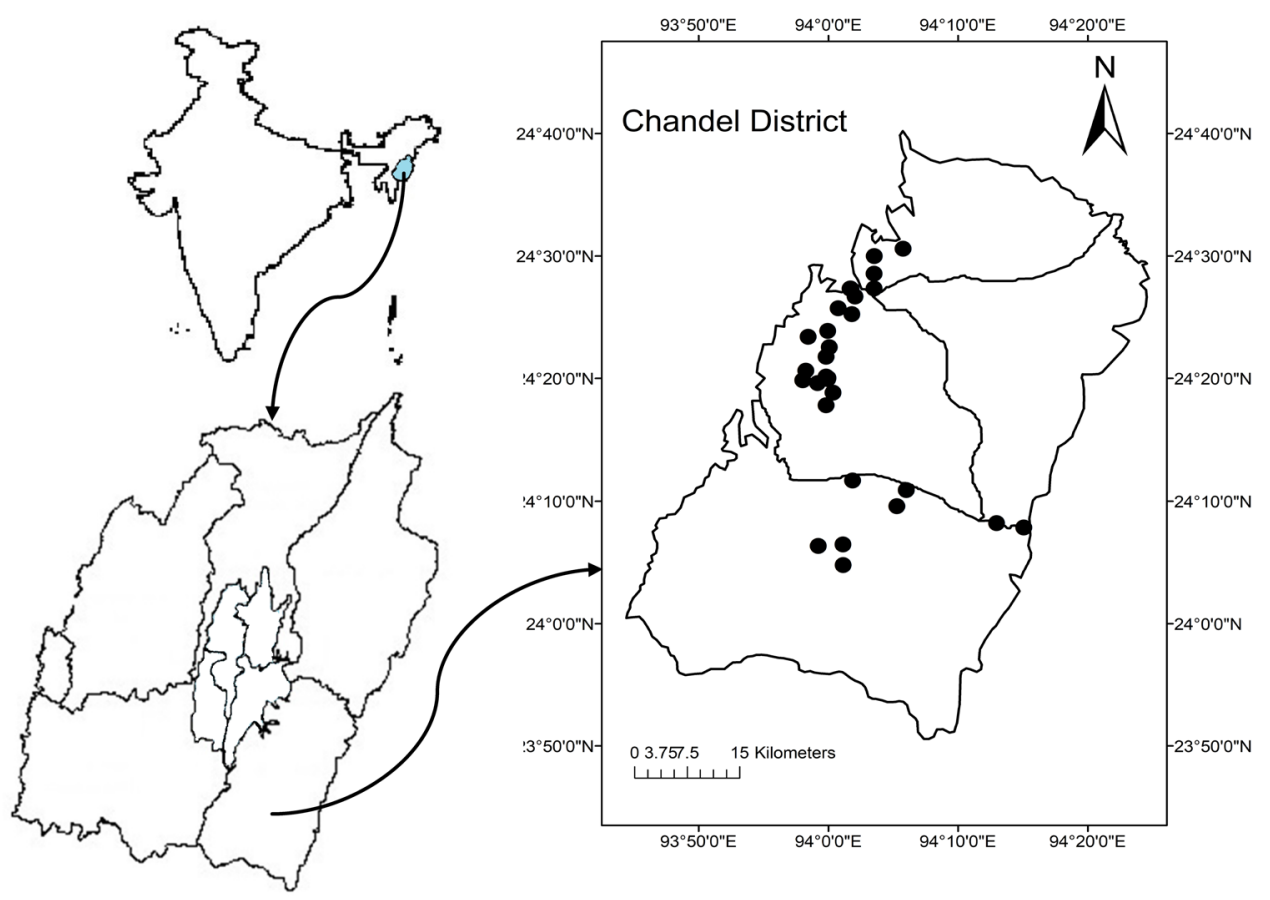
in the field using field test probes/sensor (Extech, FL700) and reverified using ion meter (Palintest) and spectrophotometric method (SPADNS method).

\section{Evaluation of drinking water quality index (WQI)}

Water quality index (WQI) is a collective numerical rating of water quality parameters which highlight the influences of various parameters on the overall quality of water for specific use (Hameed et al. 2010; Ramakrishnaiah et al. 2009). WQI was calculated for assessing suitability of groundwater for potable use based on WHO standards (WHO 2011). The calculation of WQI is based on assigning different weightage $\left(W_{i}\right)$ to water quality parameters under consideration according to their significant influence on overall drinking water quality. Finally, the relative weightage $\left(W_{\mathrm{r}}\right)$ for each parameter are calculated using the following equation:

$W_{\mathrm{r}}=\frac{W_{i}}{\sum W_{i}}$,

where $i$ represent the number of parameter considered for the calculation of WQI. The water quality rating scale $\left(Q_{i}\right)$ for each parameter were determined in accordance with their respective drinking water quality standards prescribed by WHO, using the following equation:

$Q_{i}=\left(\frac{C_{i}}{S_{i}}\right) \times 100$,

where $C_{i}$ represents the concentration of parameters and $S_{\mathrm{i}}$ represents the drinking water quality standards for each parameter according to WHO (2011). Finally, the sub-indices $\left(\mathrm{SI}_{i}\right)$ and aggregate WQI are evaluated using the following equations:

$\mathrm{SI}_{i}=W_{\mathrm{r}} \times Q_{i}$

$\mathrm{WQI}=\sum \mathrm{SI}_{i}$

The status of the drinking water quality was assessed and classified based on the aggregate WQI, calculated as unsuitable (WQI $>300)$, very poor $(200<\mathrm{WQI}<300)$, poor $(100<\mathrm{WQI}<200)$, good $(50<\mathrm{WQI}<100)$ and excellent (WQI $<50$ ) (Batabyal and Chakraborty 2015).

\section{Geochemical evaluation}

Hydrogeochemical classifications of groundwater samples were assessed by graphical plot between major cations and anions using Piper trilinear diagram (Piper 1953). This graphical plot distinctly categorised the major geochemical facies of groundwater and also provided an understanding on the water type. Gibbs diagrams (Gibbs 1970) represent cationic and anionic ratio as a function of TDS that are extensively used for assessing the dominant geochemical processes. Precipitation, rock weathering and evaporation dominance are the major geochemical processes that govern the dissolution of ions into the groundwater (Drever 1997). The multivariate analysis and Pearson' correlation matrix were used to establish the covariability between parameters. Principal component analysis (PCA) was applied to determine the nature of hydrogeochemical interactions of the water with aquifers. Similarly, hierarchical cluster analysis (CA) and dendrograms were used for grouping the samples on the basis of their similar hydrogeochemical characteristics (Prusty et al. 2018).

\section{Evaluation of irrigation water quality}

Electrical conductivity (EC) is an irrigational water quality indicator that signifies the salinity hazard. Alkali hazards such as sodium absorption ratio (SAR), residual sodium carbonate (RSC) and permeability index (PI) are extensively used for the appraisal of irrigation water quality. The alkali hazards represented by the percentage of sodium (\% $\mathrm{Na}$ ) can be expressed as shown below (where concentrations of ionic species are in $\mathrm{meq} / \mathrm{l}$ ):

$\% \mathrm{Na}=\frac{(\mathrm{Na}+\mathrm{K})}{(\mathrm{Ca}+\mathrm{Mg}+\mathrm{Na}+\mathrm{K})} \times 100$

Sodium absorption ratio (SAR) is another important parameter for evaluation of sodium or alkali hazard, which is expressed as given below:

$\mathrm{SAR}=\frac{\mathrm{Na}^{+}}{\sqrt{\left(\mathrm{Ca}^{2+}+\mathrm{Mg}^{2+}\right) / 2}}$

Similarly, residual sodium carbonates (RSCs) determine the impacts of carbonate and bicarbonate of the water on soil. High RSC value in water signifies scope for greater absorbability of sodium by soil. The RSC is mathematically expressed by the given relation:

$\mathrm{RSC}=\left(\mathrm{CO}_{3}^{2-}+\mathrm{HCO}_{3}^{-}\right)-\left(\mathrm{Ca}^{2+}+\mathrm{Mg}^{2+}\right)$

The permeability index (PI) is also another criterion for classification of irrigational water that can be defined as given below:

$\mathrm{PI}=\frac{\left(\mathrm{Na}^{+}+\sqrt{\mathrm{HCO}_{3}^{-1}}\right)}{\left(\mathrm{Ca}^{2+}+\mathrm{Mg}^{2+}+\mathrm{Na}^{+}\right)} \times 100$,

where the ionic concentrations are expressed in meq/l. The permeability index (PI) of groundwater samples is classified as per Doneen (1964) classification. Similarly, Wilcox

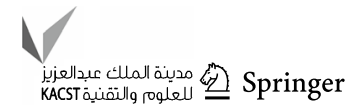


diagram represents plots between alkali (sodium) hazards (SAR) with EC, as an index for salinity hazards (Wilcox 1955). United States Salinity Laboratory Staff (USSLS 1954) diagram is also widely used to classify and rate the irrigation water quality into 16 classes based on plotting between sodium (alkali) hazards (SAR) with respect to salinity hazards (EC) (Richards 1954).

\section{Results and discussion}

Eighteen (18) physico-chemical parameters were analysed for 33 spatially distributed groundwater samples from the selected habitations of the Chandel district. The descriptive statistics including absolute and relative deviations, percentage of samples exceeding WHO permissible limit are presented in Table 1.

\section{Evaluation of groundwater quality parameters}

In situ parameters including temperature, $\mathrm{pH}, \mathrm{EC}$, TDS, salinity, ORP, DO and fluoride $\left(\mathrm{F}^{-}\right)$concentrations were assessed in the field condition using the field test probes/ sensors. The $\mathrm{pH}$ values range between 5.97 and 8.67 with the average of $6.77 \pm 0.01$. The concentrations of TDS of the samples range between 70 and $460 \mathrm{mg} / \mathrm{l}$ with an higher average value of $234.3 \pm 17.8 \mathrm{mg} / \mathrm{l}$, which signifies dissolution of lithophilic ions into the groundwater samples. Similarly, EC values range between 140 and $900 \mu \mathrm{S} / \mathrm{cm}$ with an average of $477.0 \pm 35.5 \mu \mathrm{S} / \mathrm{cm}$. Exceeding values of EC in some of the samples indicate the presence of geogenic inorganic ions, released from dissolution of rocks and mineral due rockweathering process. This is further confirmed by high degree of correlation between TDS and EC $\left(R^{2}=0.81\right)$, salinity and TDS $\left(R^{2}=0.61\right)$ and salinity with EC $\left(R^{2}=0.68\right)$. Although these parameters exhibit high degree of correlation, greater spatial variabilities were observed among the groundwater samples. Dissolved oxygen (DO) concentration was found within the desirable range (4.75-7.94 ppm) with $11.5 \%$ spatial variability. The samples exhibit positive ORP values $(79-222 \mathrm{mV})$ with an average of $202.3 \pm 4.94 \mathrm{mV}$, indicating oxidising potential of water and presence of redox-active salts, minerals and metal ions. Groundwater confirms the presence of bicarbonate $\left(\mathrm{HCO}_{3}{ }^{-}\right)$alkalinity with $48.7 \%$ of spatial variability. Similarly, $78.8 \%$ of groundwater samples exhibit moderately hard water, followed by $15.2 \%$ hard and $6.1 \%$ very hard water as per USGS hardness classification (Briggs and Ficke 1977) (Table 2). The hardness of groundwater results due to the presence of both carbonate and non-carbonate salts, as $\mathrm{Cl}^{-}$concentration was found in higher range of 4.0-110 mg/l (59.2 $\pm 3.9 \mathrm{mg} / \mathrm{l})$ (Table 1). Sodium $\left(\mathrm{Na}^{+}\right)$shows elevated concentrations $(96.6 \%)$ than the permissible limit of WHO, ranging between 21.64 and $472.2 \mathrm{mg} / \mathrm{l}$ (average of $119.1 \pm 20.72 \mathrm{mg} / \mathrm{l}$ ) with greater spatial variability. The $\mathrm{NO}_{3}{ }^{-}$and $\mathrm{PO}_{4}{ }^{3-}$ show average of $33.4 \pm 5.81 \mathrm{mg} / \mathrm{l}$ and $36.6 \pm 0.01 \mathrm{mg} / \mathrm{l}$, respectively,
Table 1 The descriptive statistics of groundwater parameters of the study area

\begin{tabular}{|c|c|c|c|c|c|c|c|}
\hline Parameters & Units & Min & Max & Avg & SD & $\mathrm{CV}$ & $\begin{array}{l}\text { Samples beyond } \\
\text { WHO permissible } \\
\text { limit }(\%)\end{array}$ \\
\hline Temp & ${ }^{\circ} \mathrm{C}$ & 16.90 & 19.70 & 19.35 & 0.57 & 2.94 & - \\
\hline $\mathrm{pH}$ & - & 5.97 & 8.67 & 6.77 & 0.46 & 6.81 & 15 \\
\hline EC & $\mu \mathrm{S} / \mathrm{cm}$ & 140.0 & 900.0 & 477.0 & 204.0 & 42.8 & 75.8 \\
\hline Salt & ppt & 0.01 & 0.30 & 0.16 & 0.07 & 46.21 & 54.5 \\
\hline ORP & $\mathrm{mV}$ & 79.0 & 222.0 & 202.3 & 28.4 & 14.0 & - \\
\hline TDS & ppm & 70.0 & 460.0 & 234.3 & 102.0 & 43.5 & 24.2 \\
\hline DO & $\mathrm{ppm}$ & 4.58 & 7.94 & 7.13 & 0.82 & 11.49 & 3 \\
\hline $\mathrm{HCO}_{3}^{-}$ & $\mathrm{mg} / \mathrm{l}$ & 9.81 & 50.00 & 17.02 & 8.29 & 48.68 & 0 \\
\hline $\mathrm{TH}$ as $\mathrm{CaCO}_{3}$ & $\mathrm{mg} / \mathrm{l}$ & 60.0 & 225.0 & 106.0 & 34.19 & 32.27 & 0 \\
\hline $\mathrm{Ca}^{2+}$ & $\mathrm{mg} / \mathrm{l}$ & 20.01 & 74.08 & 45.99 & 13.66 & 29.69 & 3 \\
\hline $\mathrm{Mg}^{2+}$ & $\mathrm{mg} / \mathrm{l}$ & 0.01 & 42.53 & 11.73 & 9.67 & 82.48 & 6.1 \\
\hline $\mathrm{Cl}^{-}$ & $\mathrm{mg} / \mathrm{l}$ & 24.99 & 109.97 & 59.23 & 22.53 & 38.04 & 0 \\
\hline $\mathrm{F}^{-}$ & $\mathrm{mg} / \mathrm{l}$ & BDL & 1.65 & 0.68 & 0.49 & 72.62 & 27.3 \\
\hline $\mathrm{Na}^{+}$ & $\mathrm{mg} / \mathrm{l}$ & 21.64 & 472.22 & 189.02 & 119.05 & 62.98 & 96.6 \\
\hline $\mathrm{K}^{+}$ & $\mathrm{mg} / \mathrm{l}$ & 4.08 & 253.75 & 50.81 & 57.52 & 113.21 & 0 \\
\hline $\mathrm{NO}_{3}^{-}$ & $\mathrm{mg} / \mathrm{l}$ & 0.03 & 146.76 & 40.47 & 33.37 & 82.47 & 36.4 \\
\hline $\mathrm{SO}_{4}{ }^{2-}$ & $\mathrm{mg} / \mathrm{l}$ & 6.65 & 145.22 & 58.13 & 36.61 & 62.99 & 0 \\
\hline $\mathrm{PO}_{4}{ }^{3-}$ & $\mathrm{mg} / \mathrm{l}$ & 0.01 & 0.50 & 0.19 & 0.13 & 68.41 & 0 \\
\hline
\end{tabular}

$B D L$ below detection limit $(<0.01 \mathrm{mg} / \mathrm{l})$ 
Table 2 USGS hardness classification of groundwater samples for the study area

\begin{tabular}{lllc}
\hline Hardness classification & $\begin{array}{l}\text { Hardness as } \mathrm{CaCO}_{3} \\
(\mathrm{mg} / \mathrm{l})\end{array}$ & Representative samples & Samples (\%) \\
\hline Soft & $0-60$ & $\mathrm{Nil}$ & 0 \\
Moderately hard & $60-120$ & $\mathrm{~S}-1, \mathrm{~S}-2, \mathrm{~S}-3, \mathrm{~S}-4, \mathrm{~S}-5, \mathrm{~S}-6, \mathrm{~S}-7, \mathrm{~S}-8, \mathrm{~S}-10, \mathrm{~S}-12, \mathrm{~S}-13, \mathrm{~S}-14, \mathrm{~S}-15, \mathrm{~S}-16$, & 78.8 \\
& & $\mathrm{~S}-17, \mathrm{~S}-18, \mathrm{~S}-19, \mathrm{~S}-20, \mathrm{~S}-21, \mathrm{~S}-22, \mathrm{~S}-23, \mathrm{~S}-24, \mathrm{~S}-26, \mathrm{~S}-27, \mathrm{~S}-30, \mathrm{~S}-31$ & 15.2 \\
Hard & $121-180$ & $\mathrm{~S}-29, \mathrm{~S}-9, \mathrm{~S}-28, \mathrm{~S}-11, \mathrm{~S}-25$ & 6.1 \\
Very hard & $>180$ & $\mathrm{~S}-32, \mathrm{~S}-33$ & \\
\hline
\end{tabular}

with $82.5 \%$ of spatial variability in nitrate concentration of the samples. Sulphate concentration ranges between $6.65 \pm 145.22 \mathrm{mg} / \mathrm{l}$ which is less than the permissible limit of $200 \mathrm{mg} / \mathrm{l}$ (WHO 2011). The authors anticipated that elevated concentration of sulphate in groundwater samples is due to sulphate mineral dissolution or oxidation of sulphur. Fluoride $\left(\mathrm{F}^{-}\right)$in groundwater samples ranges between BDL and $1.65 \mathrm{mg} / \mathrm{l}$ with around $27.1 \%$ samples exceeding beyond WHO permissible limit of $1.5 \mathrm{mg} / \mathrm{l}$. The highest concentration $(1.65 \mathrm{mg} / \mathrm{l})$ of fluoride $\left(\mathrm{F}^{-}\right)$was recorded in the sample of Tuishimi habitation (S-8).

\section{Water quality index (WQI)}

Suitability for drinking water quality of the selected habitations was evaluated using water quality index (WQI). The WQI ranges from 32.5 to 106.1 , where around $21.2 \%$ of samples fall in the category of excellent water, followed by $75.8 \%$ and $3.1 \%$ samples in the good and poor water quality, respectively (Fig. 2). Concentrations of dissolved ions such as $\mathrm{F}^{-}, \mathrm{Cl}^{-}$and $\mathrm{NO}_{3}{ }^{-}$and higher $\mathrm{EC}$ value of the samples influence the WQI of samples for the habitations. Moreover, samples with higher $\mathrm{F}^{-}$concentration exhibit higher WQI values, considered to be unsuitable for potable use (Table 3). The predicted spatial distribution map for WQI (Fig. 3a) and fluoride $\left(\mathrm{F}^{-}\right)$concentration (Fig. 3b) for the study area was prepared using inverse-distance weighting (IDW) geospatial interpolation techniques in the ArcGIS platform. The tool is extensively used for preparation of spatial distribution maps for various water quality parameters based on interpolation techniques such as kriging and IDW (Kresic 1997). The figure highlights the probable pockets of $\mathrm{F}^{-}$bearing aquifers in the region.

\section{Correlation analysis}

Correlation analysis between the physico-chemical parameters of the groundwater samples was carried out to identify the influence of the variables and also to predict the dependency of variables on each other. The linear and multiple coefficient of correlation $(r)$ was estimated between the variables that range between -1 and +1 and are classified as strong $( \pm 0.7<r< \pm 1)$, moderate $( \pm 0.5<r< \pm 0.7)$ and weak $(0<r< \pm 0.5)$ correlation depending on the influences of parameters on each other and with WQI. The higher concentration of EC, TDS, $\mathrm{Na}^{+}, \mathrm{PO}_{4}{ }^{3-}$ and $\mathrm{SO}_{4}{ }^{2-}$ exhibits higher correlation with WQI (Table 4). The EC shows strong correlation with salinity (0.83), TDS $(0.90)$ and $\mathrm{SO}_{4}{ }^{2-}(0.87)$ and $\mathrm{Na}^{+}(0.87)$ at $p<0.05$. The strong correlation between EC and TDS indicates that conductivity of the groundwater samples increases due to dissolutions of more dissolved inorganic ions. Similarly, strong correlation between EC and $\mathrm{Na}^{+}, \mathrm{HCO}_{3}{ }^{-}, \mathrm{NO}_{3}{ }^{-}$and $\mathrm{SO}_{4}{ }^{2-}$ indicates the influences of ions that have resulted from various geochemical interactions such as oxidation-reduction and ion-exchange processes. TDS also reveals strong correlation with TH (0.76), salts (0.78), $\mathrm{Na}^{+}(0.76), \mathrm{SO}_{4}{ }^{2-}(0.71)$ (at $\left.p<0.05\right)$, indicating that TDS and hardness are two main contributing factors for
Fig. 2 Categorisation of groundwater samples based on WQI w.r.t WHO standards

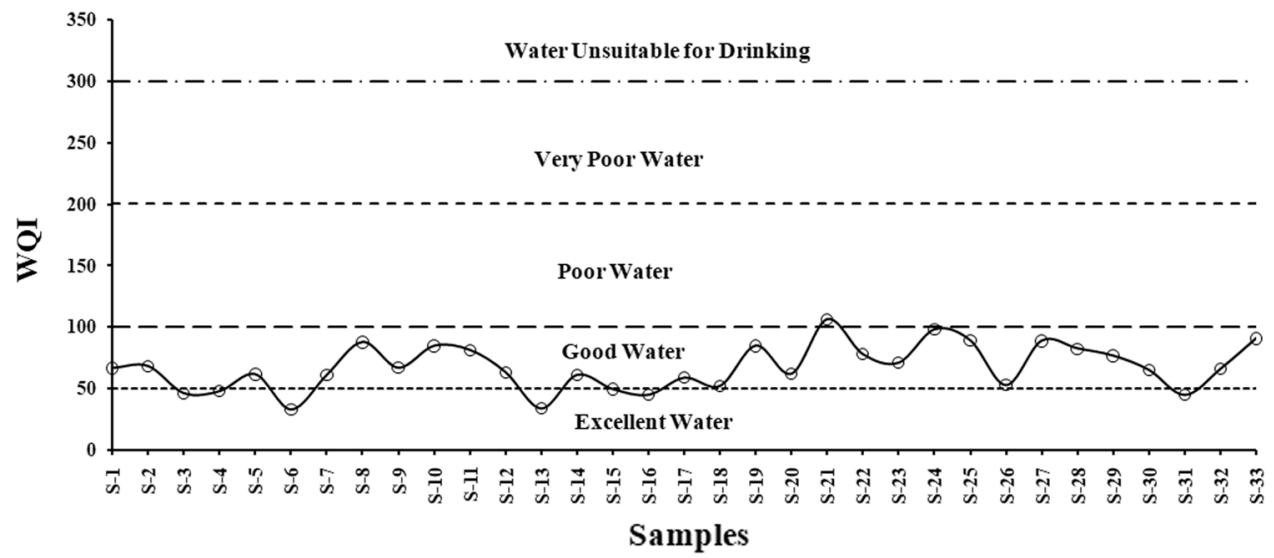

Samples 
Table 3 Standards $\left(S_{i}\right)$, assigned weight $\left(W_{i}\right)$ and relative weight $\left(W_{\mathrm{r}}\right)$ for evaluation of WQI

\begin{tabular}{|c|c|c|c|c|}
\hline Sl. no. & Chemical parameter & WHO $\left(S_{i}\right)$ & Weight $\left(W_{i}\right)$ & $\begin{array}{l}\text { Relative } \\
\text { weight } \\
\left(W_{\mathrm{r}}\right)\end{array}$ \\
\hline 1 & $\mathrm{pH}$ & $6.5-8.5$ & 4 & 0.0833 \\
\hline 2 & Fluoride $\left(\mathrm{F}^{-}\right)$ & $1.5 \mathrm{mg} / \mathrm{l}$ & 5 & 0.1042 \\
\hline 3 & Chloride $\left(\mathrm{Cl}^{-}\right)$ & $250-1000 \mathrm{mg} / \mathrm{l}$ & 4 & 0.0833 \\
\hline 4 & Electrical conductivity (EC) & $500 \mu \mathrm{S} / \mathrm{cm}$ & 3 & 0.0625 \\
\hline 5 & Alkalinity $\left(\mathrm{HCO}_{3}^{-}\right)$ & $244-732 \mathrm{mg} / \mathrm{l}$ & 3 & 0.0625 \\
\hline 6 & $\mathrm{TH}$ as $\mathrm{CaCO}_{3}$ & $300-600 \mathrm{mg} / \mathrm{l}$ & 3 & 0.0625 \\
\hline 7 & Dissolved oxygen (DO) & $4-6 \mathrm{mg} / \mathrm{l}$ & 4 & 0.0833 \\
\hline 8 & Total dissolved solids (TDS) & $500-2000 \mathrm{mg} / \mathrm{l}$ & 3 & 0.0625 \\
\hline 9 & Calcium $\left(\mathrm{Ca}^{2+}\right)$ & $75-200 \mathrm{mg} / \mathrm{l}$ & 2 & 0.0417 \\
\hline 10 & Magnesium $\left(\mathrm{Mg}^{2+}\right)$ & $30-100 \mathrm{mg} / \mathrm{l}$ & 2 & 0.0417 \\
\hline 11 & Sodium $\left(\mathrm{Na}^{+}\right)$ & $200 \mathrm{mg} / \mathrm{l}$ & 2 & 0.0417 \\
\hline 12 & Potassium $\left(\mathrm{K}^{+}\right)$ & $300 \mathrm{mg} / \mathrm{l}$ & 2 & 0.0417 \\
\hline 13 & Nitrate $\left(\mathrm{NO}_{3}^{-}\right)$ & $45-100 \mathrm{mg} / \mathrm{l}$ & 5 & 0.1042 \\
\hline 14 & Sulphate $\left(\mathrm{SO}_{4}^{2-}\right)$ & $200-400 \mathrm{mg} / \mathrm{l}$ & 3 & 0.0625 \\
\hline \multirow[t]{2}{*}{15} & Phosphate $\left(\mathrm{PO}_{4}{ }^{3-}\right)$ & $0.1 \mathrm{mg} / \mathrm{l}$ & 3 & 0.0625 \\
\hline & & & $\Sigma=48$ & $\Sigma=1$ \\
\hline
\end{tabular}

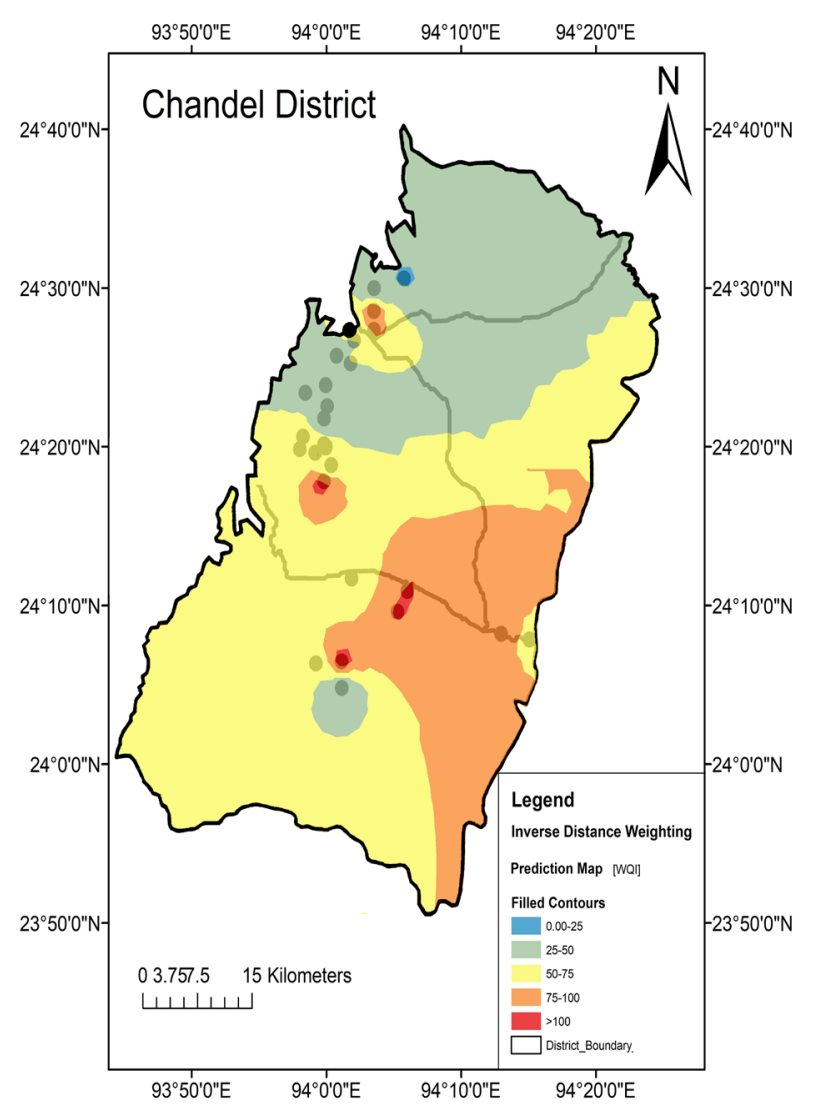

(a)

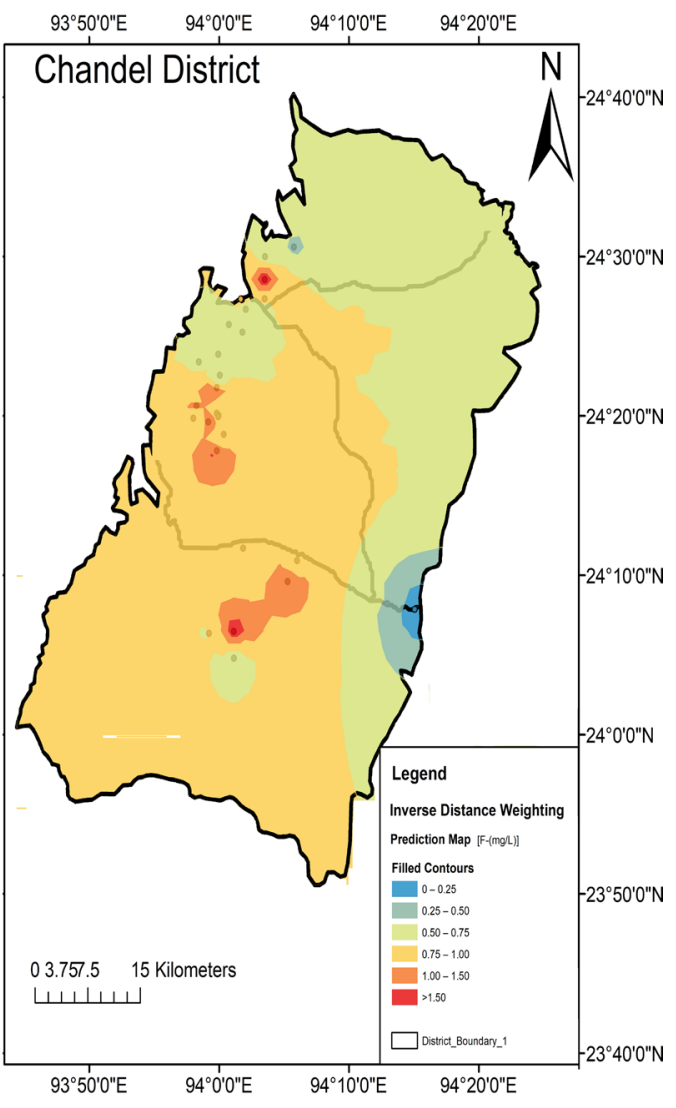

(b)

Fig. 3 Predicted geospatial distribution map for $\mathbf{a}$ water quality index (WQI) and $\mathbf{b}$ fluoride $\left(\mathrm{F}^{-}\right)$concentration, for the study area 


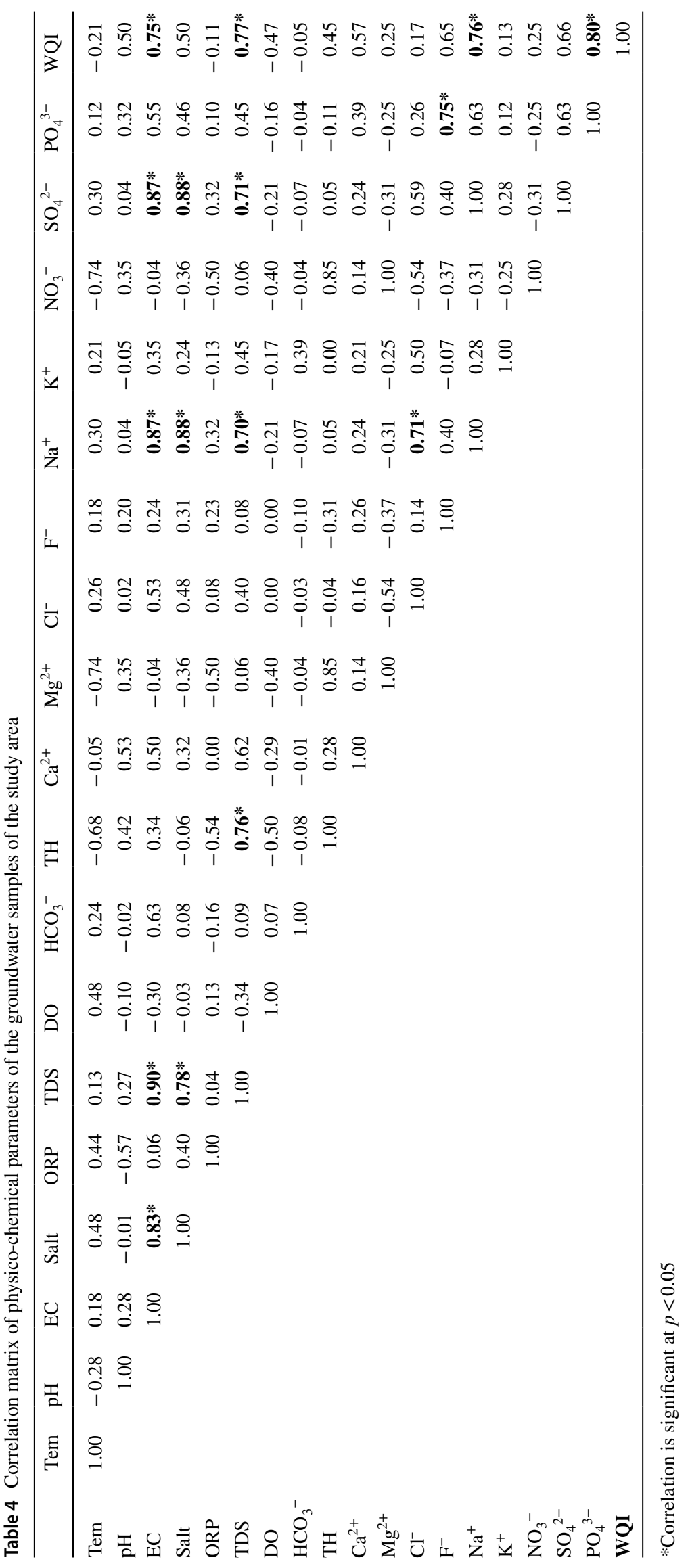


alkali hazard and non-carbonate hardness $\left(\mathrm{Cl}^{-}\right.$and $\left.\mathrm{SO}_{4}{ }^{2-}\right)$ in the majority of the samples. Moreover, $\mathrm{SO}_{4}{ }^{2-}$ exhibits strong correlation with salinity $(0.88)$ and $\mathrm{PO}_{4}{ }^{3-}$ exhibits strong correlation with $\mathrm{F}^{-}(0.75)$, indicating dissolution of phosphorite minerals such as apatite (hydroxyapatite, fluorapatite) in the aquifer.

\section{Geochemical classification}

Geochemical classification and characterisation of groundwater samples for the study area were carried out using a geochemical diagnostic tool for better visual interpretation. The Piper trilinear diagram (Fig. 4) exhibits general trend of dominance of major cations and anions in the order of $\mathrm{Na}^{+}>\mathrm{Ca}^{2+}>\mathrm{Mg}^{2+}>\mathrm{K}^{+}$type and $\mathrm{Cl}^{-}>\mathrm{HCO}_{3}{ }^{-}>\mathrm{SO}_{4}{ }^{2-}>\mathrm{NO}_{3}{ }^{-}$type, respectively. The figure also reveals that the majority of geochemical facies of groundwater samples are dominated by $\mathrm{Na}^{+}-\mathrm{Ca}^{2+}-\mathrm{Mg}^{2+}-\mathrm{Cl}^{-}-\mathrm{HCO}_{3}{ }^{-}-\mathrm{SO}_{4}{ }^{2-}$-type of water, followed by $\mathrm{Na}^{+}-\mathrm{Ca}^{2+}-\mathrm{K}^{+}-\mathrm{Cl}^{-}-\mathrm{HCO}_{3}{ }^{-}$type of water. Classification of dominant geochemical process was carried out using Gibbs diagram (Fig. 5), which is extensively used for assessing the major geochemical processes that governs

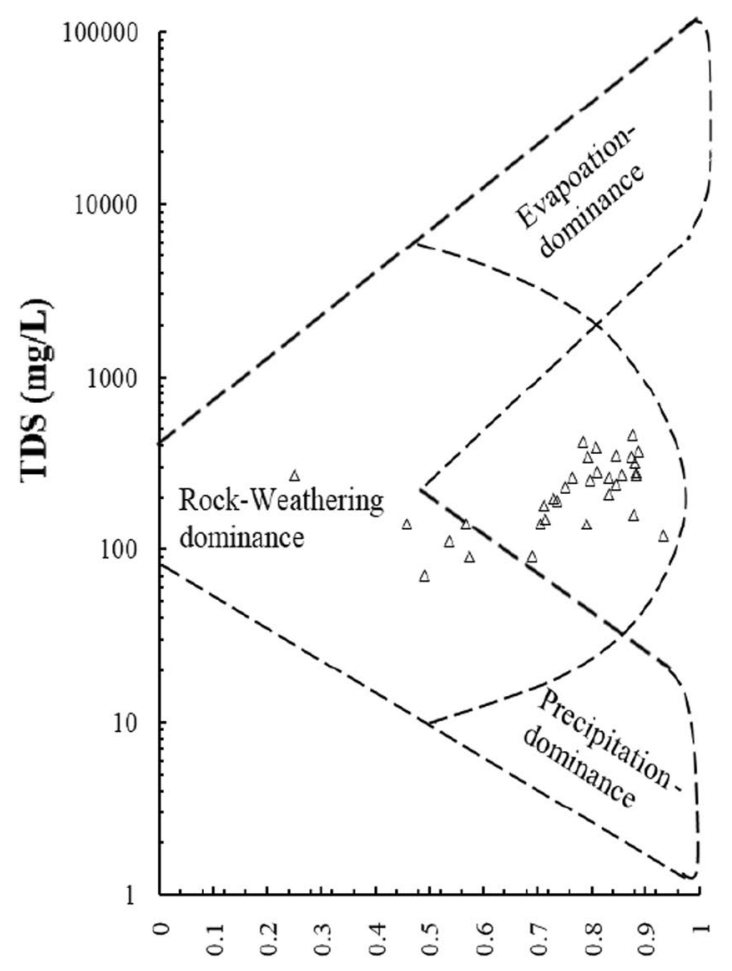

$\left(\mathrm{Na}^{+}+\mathrm{K}^{+}\right):\left(\mathrm{Na}^{+}+\mathrm{K}^{+}+\mathrm{Ca}^{2+}\right)($ meq/L)

(a) Cations

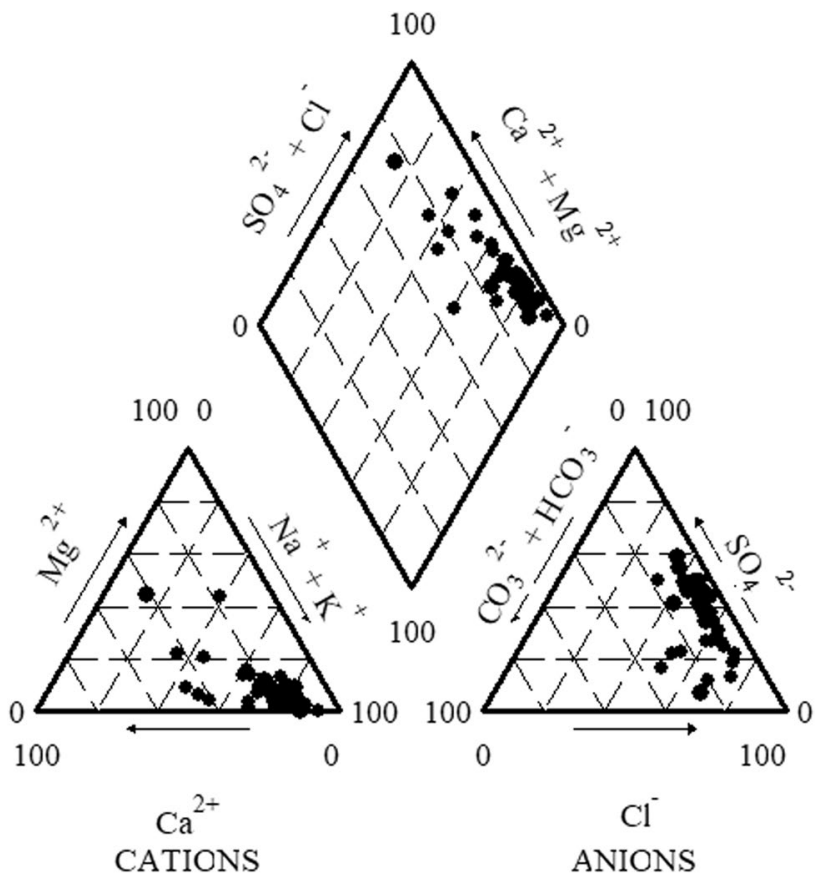

Fig. 4 Piper diagram representing the major geochemical facies of groundwater resources for the habitations in the study area

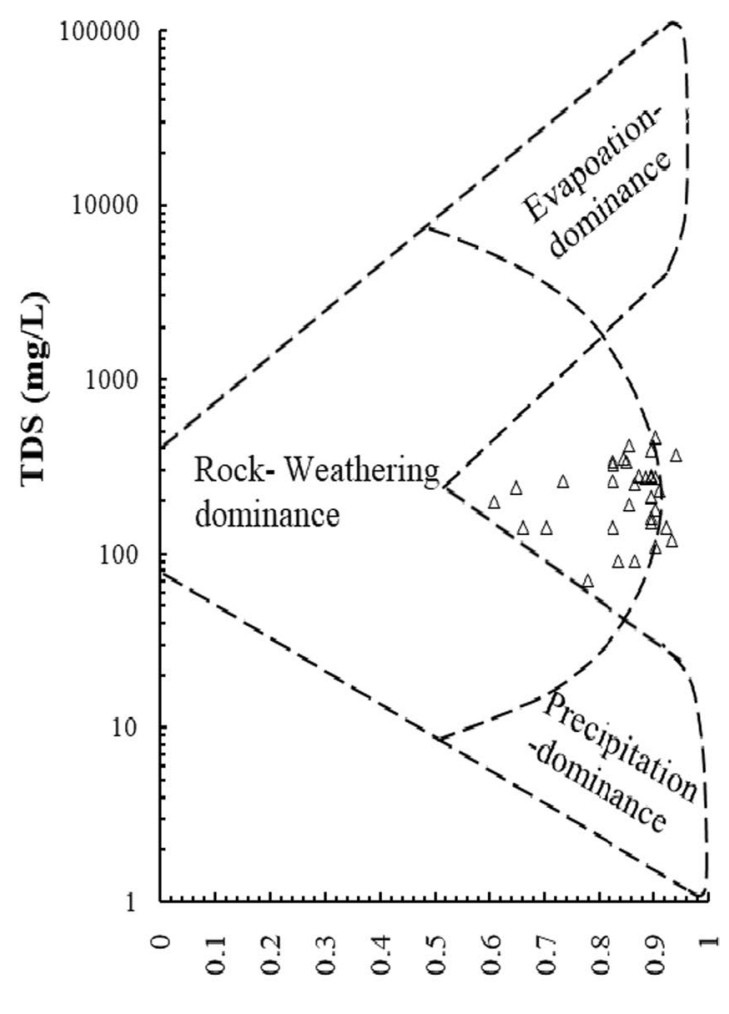

$\mathrm{Cl}^{-} /\left(\mathrm{Cl}^{--}+\mathrm{HCO}_{3}^{--}\right)(\mathrm{meq} / \mathrm{L})$

(b) Anions

Fig. 5 Gibbs diagram showing rock weathering as a dominant geochemical process for dissolution of $\mathbf{a}$ cations and $\mathbf{b}$ anions in the groundwater samples for the study area 
the water type and ion chemistry in the aquifers. The figure exhibits that the rock weathering is a major dominant geochemical process that governs the release of ions into the groundwater of the study area.

\section{Principal component analysis (PCA)}

The principal component analysis (PCA) was applied to determine the nature of variations in hydrogeochemical interactions of the water quality parameters (Prusty et al. 2018). The five principal components (PCs) are presented in Table 5 (with eigenvalue $>1$ ), which accounts for $83.0 \%$ of variances in the hydrogeochemical variables. The PC-1 accounts for $34.4 \%$, PC-2 accounts for $59.0 \%$, PC-3 accounts for $69.0 \%$, PC- 4 accounts for $77.2 \%$, and PC-5 accounts for $83.0 \%$ of variances within the variables, respectively. The PCs identify the underlying hydrogeochemical processes, and it is fairly distinct that about $34.4 \%$ of variances of the data are highly correlated with EC, salinity, TDS, $\mathrm{Cl}^{-}, \mathrm{Na}^{+}$, $\mathrm{SO}_{4}{ }^{2-}$ and $\mathrm{PO}_{4}{ }^{3-}$. But it can also be seen that variances of the variables are inversely correlated with $\mathrm{NO}_{3}{ }^{-}, \mathrm{Mg}^{2+}$, DO and TH. Similarly, PC-2 indicates $24.6 \%$ of variances in the variables are correlated with $\mathrm{TH}, \mathrm{Mg}^{2+}$ and $\mathrm{NO}_{3}{ }^{-}$and inversely correlated with temperature, ORP, $\mathrm{DO}, \mathrm{HCO}_{3}{ }^{-}$and $\mathrm{F}^{-}$, respectively. Occurrences of these variances among the variables are expected due to intrusion of surface water from heavy precipitation in the region $(>1036 \mathrm{~mm} / \mathrm{year})$ and dissolution of ions in the aquifer. Moreover, shallowness of the aquifers (10-20 m bgl) (CGWB 2013) in the region may be another attributing factor.

\section{Cluster analysis (CA)}

The hierarchical cluster analysis (CA) was applied to determine and group the samples on the basis of their spatial similar characteristics. The cluster analysis indicates four major clusters or groups of water types, i.e. groups I, II, III and IV (Fig. 6; Table 5). The groups show the considerable spatial variability of water quality parameters due to variability of the aquifer types and their formations. Most of the samples are collected from wells, tube wells and springs that occur under unconfined aquifer condition and are mostly shallow in nature. EC value varies from 470 to $540 \mu \mathrm{S} /$ cm (group I), 140-210 $\mu \mathrm{S} / \mathrm{cm}$ (group II), $270-390 \mu \mathrm{S} / \mathrm{cm}$ (group III) and 630-900 $\mu \mathrm{S} / \mathrm{cm}$ (group IV). Thus, group IV samples are categorised together for the samples with higher concentrations of $\mathrm{Cl}^{-}, \mathrm{Ca}^{2+}, \mathrm{Na}^{+}, \mathrm{EC}$, TDS, salinity, $\mathrm{TH}$, indicating mostly non-carbonate hardness of water characterised by $\mathrm{NaCl}, \mathrm{CaCl}_{2}$ type of water. Also, group IV shows higher concentration of $\mathrm{Na}^{+}(247.4-472.2 \mathrm{mg} / \mathrm{l})$ and $\mathrm{Cl}^{-}$(44.9-110.0 mg/l), indicating $\mathrm{NaCl}$ type of water resulting from dissolution of halite, as the region is having evidence of the presence of saline springs (Singh et al. 2013;
Table 5 Varimax rotated factor loadings with eigenvalues and $\%$ of variances for the groundwater quality parameters

\begin{tabular}{|c|c|c|c|c|c|}
\hline \multirow[t]{2}{*}{ Parameters } & \multicolumn{5}{|c|}{ Component } \\
\hline & PC-1 & PC-2 & PC-3 & PC-4 & PC-5 \\
\hline Tem & 0.53 & -0.63 & 0.19 & 0.12 & 0.30 \\
\hline $\mathrm{pH}$ & 0.03 & 0.61 & -0.24 & 0.61 & -0.06 \\
\hline $\mathrm{EC}$ & 0.82 & 0.51 & 0.09 & -0.09 & 0.06 \\
\hline Salt & 0.89 & 0.09 & 0.05 & -0.19 & 0.24 \\
\hline ORP & 0.40 & -0.51 & -0.23 & -0.49 & 0.31 \\
\hline TDS & 0.75 & 0.56 & 0.22 & -0.04 & 0.19 \\
\hline DO & -0.06 & -0.62 & 0.01 & 0.27 & 0.12 \\
\hline $\mathrm{HCO}_{3}^{-}$ & 0.04 & -0.06 & 0.58 & 0.41 & 0.47 \\
\hline $\mathrm{TH}$ & -0.21 & 0.91 & 0.13 & -0.17 & -0.09 \\
\hline $\mathrm{Ca}^{2+}$ & 0.38 & 0.52 & -0.13 & 0.33 & 0.23 \\
\hline $\mathrm{Mg}^{2+}$ & -0.57 & 0.77 & -0.03 & -0.15 & 0.20 \\
\hline $\mathrm{Cl}^{-}$ & 0.73 & -0.03 & 0.30 & 0.04 & -0.57 \\
\hline $\mathrm{F}^{-}$ & 0.50 & -0.10 & -0.65 & 0.35 & -0.01 \\
\hline $\mathrm{Na}^{+}$ & 0.91 & 0.21 & -0.06 & -0.24 & -0.05 \\
\hline $\mathrm{K}^{+}$ & 0.41 & 0.08 & 0.69 & 0.25 & -0.18 \\
\hline $\mathrm{NO}_{3}^{-}$ & -0.57 & 0.77 & -0.03 & -0.15 & 0.20 \\
\hline $\mathrm{SO}_{4}{ }^{2-}$ & 0.91 & 0.21 & -0.06 & -0.24 & -0.05 \\
\hline $\mathrm{PO}_{4}{ }^{3-}$ & 0.78 & 0.19 & -0.46 & 0.29 & 0.00 \\
\hline Eigenvalues & 6.20 & 4.42 & 1.79 & 1.49 & 1.03 \\
\hline Variability (\%) & 34.43 & 24.58 & 9.97 & 8.26 & 5.71 \\
\hline Cumulative (\%) & 34.43 & 59.02 & 68.98 & 77.24 & 82.95 \\
\hline
\end{tabular}

Values in bold indicates significant factor loadings

CGWB 2013). Similarly, salinity of groups I and IV was found to be higher (0.2-0.3 ppt), indicating halite-dominated aquifer formations. As per the hardness classification, groups I, II and IV represent more non-carbonate types of hardness as $\mathrm{HCO}_{3}{ }^{-}$concentrations are comparatively lower in each group. Moreover, $\mathrm{Ca}^{2+}+\mathrm{Mg}^{2+}$ versus $\mathrm{HCO}_{3}{ }^{-}+\mathrm{SO}_{4}{ }^{2-}$ ratio is slightly lesser than unity, whereas $\mathrm{Na}^{+} / \mathrm{Cl}^{-}$is greater than unity, indicating ion-exchange silicate weathering.

\section{Irrigation water quality}

Suitability of irrigation water quality was evaluated using water quality parameters such as EC, TDS and irrigational water quality indices such as sodium percentage $(\% \mathrm{Na})$, sodium absorption ratio (SAR), residual sodium carbonate (RSC), permeability index (PI), USSLS and Wilcox diagram. The irrigational water quality is greatly influenced by EC and TDS as these two parameters represent the measure of salinity hazards which have profound effects on soil osmotic pressure (O'Geen 2015). The EC of the groundwater samples varies within $140-900 \mu \mathrm{S} / \mathrm{cm}$ with average value of $477.0 \pm 35.5 \mu \mathrm{S} / \mathrm{cm}$ (Table 6). Approximately $12.1 \%$ of samples exhibit EC concentrations beyond $750 \mu \mathrm{S} / \mathrm{cm}$, considered as harmful for irrigational uses (Richards 1954).

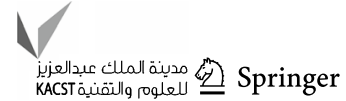


Fig. 6 Dendrogram based on hierarchical cluster analysis, highlighting on spatio-similarity of the samples for the study area

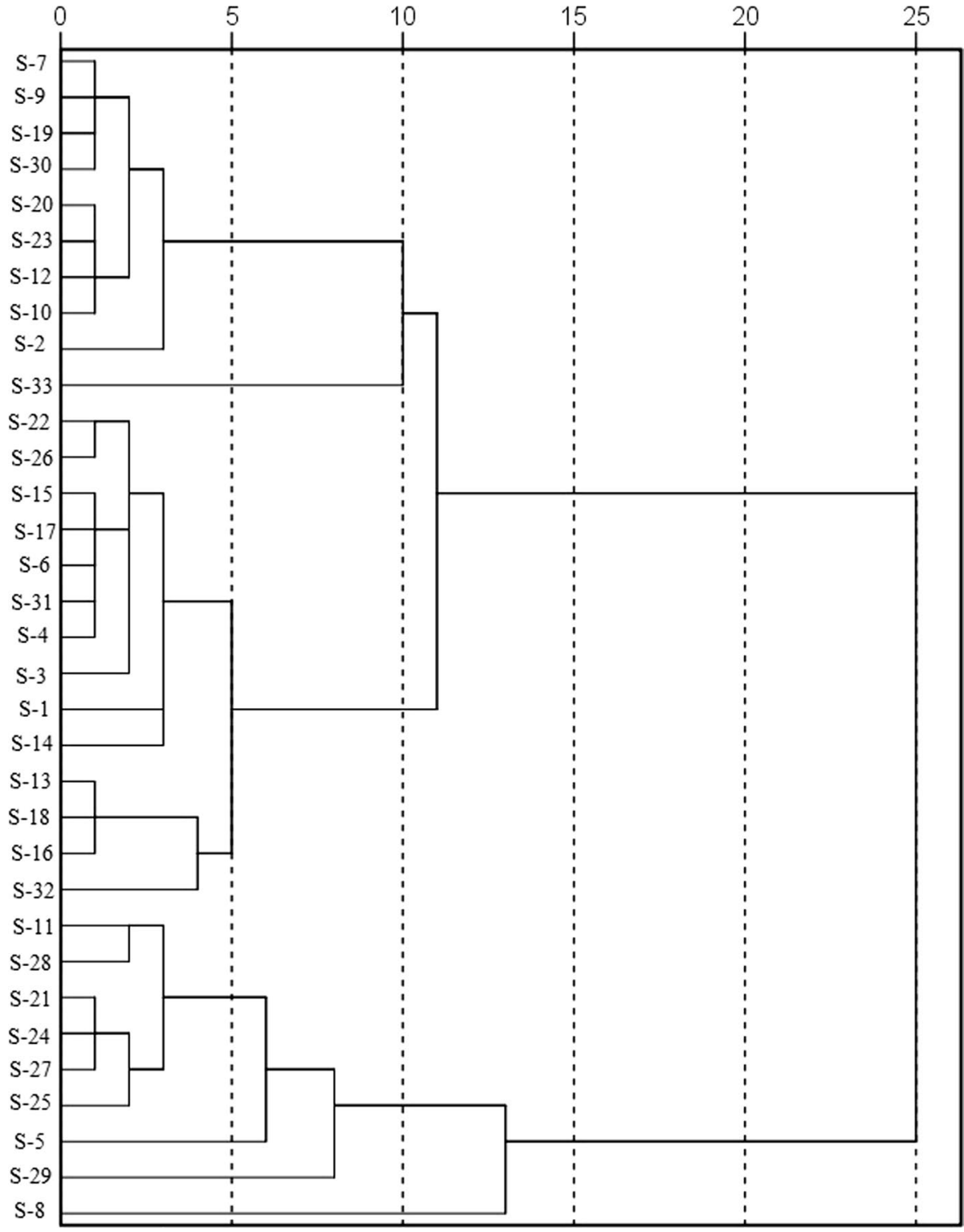

Table 6 Groups showing similar types of groundwater quality in the study area

\begin{tabular}{ll}
\hline Group & Sampling stations \\
\hline Group I & S-7, S-9, S-19, S-30, S-20, S-23, S-12, S-10, S-2, S-33 \\
Group II & S-22, S-26, S-15, S-17, S-6, S-31, S-4, S-3, S-1, S-14 \\
Group III & S-13, S-18, S-16, S-32 \\
Group IV & S-11, S-28, S-21, S-24, S-27, S-25, S-5, S-29, S-8 \\
\hline
\end{tabular}

TDS concentrations $(70-460 \mathrm{mg} / \mathrm{l})$ indicate that most of groundwater belongs to freshwater category and suitable for irrigational use (Table 7). According to sodium percentage, groundwater samples lie within excellent to permissible category. Approximately $78.8 \%$ samples fall in the category of low alkali hazard (SAR), whereas $18.2 \%$ and
$3 \%$ of samples fall in the category of increasing problem and severe problem of alkali hazards, respectively. Similarly, PI values indicate that approx. $21.2 \%$ samples show suitability and $78.8 \%$ samples show unsuitability for irrigational uses. Likewise, RSC values (Table 7) reveal that about $9.1 \%$ of samples have possibility of impact on soil due to the presence of carbonates and bicarbonates in water and remaining $90.9 \%$ samples are safe for irrigation due to low value of RSC $(<1.25)$. Elevated RSC value in water signifies scope for greater absorption of sodium by soil (Eaton 1950). The Wilcox diagram displays plots between $\mathrm{Na} \%$ and EC (Fig. 7). The figure demonstrates approximately $15.2 \%$ of samples in the category of good to permissible range and $84.8 \%$ of samples are in the category of excellent to good range for irrigational water. The USSLS (1954) diagram classifies the irrigation water on the basis of salinity (EC) 
Table 7 Classification of groundwater for irrigational use based on irrigational indices

\begin{tabular}{|c|c|c|c|c|}
\hline Parameters & Range & Groundwater class & $\begin{array}{l}\text { Number of sam- } \\
\text { ples }\end{array}$ & $\%$ of samples \\
\hline \multirow[t]{5}{*}{ EC ( $\mu \mathrm{S} / \mathrm{cm})($ Richards 1954) } & $<250$ & Excellent & 4 & 12.1 \\
\hline & $250-750$ & Good & 25 & 75.8 \\
\hline & $750-2000$ & Permissible & 4 & 12.1 \\
\hline & $2000-3000$ & Doubtful & 0 & 0 \\
\hline & $>3000$ & Unsuitable & 0 & 0 \\
\hline \multirow[t]{5}{*}{ TDS (mg/l) (Freeze and Cherry 1979) } & $<1000$ & Freshwater & 33 & 100 \\
\hline & $1000-3000$ & Slightly saline & 0 & 0 \\
\hline & $3000-10,000$ & Moderately saline & 0 & 0 \\
\hline & $10,000-35,000$ & Highly saline & 0 & 0 \\
\hline & $>35,000$ & Brine & 0 & 0 \\
\hline \multirow[t]{5}{*}{$\% \mathrm{Na}$ (Wilcox 1955) } & $<20$ & Excellent & 23 & 69.7 \\
\hline & $20-40$ & Good & 7 & 21.2 \\
\hline & $40-60$ & Permissible & 3 & 9.1 \\
\hline & $60-80$ & Doubtful & 0 & 0 \\
\hline & $>80$ & Unsuitable & 0 & 0 \\
\hline \multirow[t]{3}{*}{ SAR (Bouwer 1978) } & $<6$ & No problem & 26 & 78.8 \\
\hline & $6-9$ & Increasing problem & 6 & 18.2 \\
\hline & $>9$ & Severe problem & 1 & 3.00 \\
\hline \multirow[t]{2}{*}{ PI (Doneen 1964) } & $<60$ & Suitable for irrigation & 7 & 21.2 \\
\hline & $>60$ & Unsuitable for irrigation & 26 & 78.8 \\
\hline \multirow[t]{2}{*}{ RSC (Eaton 1950) } & $>1.25$ & Unsuitable for irrigation & 3 & 9.1 \\
\hline & $<1.25$ & Safe for irrigation & 30 & 90.9 \\
\hline
\end{tabular}

and alkali (sodium) hazards (Fig. 8). Approximately 57.6\% of the samples exhibit medium salinity and low alkali hazards, followed by $18.1 \%$ samples in the category of high salinity and low alkali hazards (C2-S1). Similarly, approximately $12.1 \%$ samples fall in the category of low salinity and low alkali hazard (C1-S1), 6.1\% samples fall in the category of medium salinity and medium alkali hazard (C2-S2), and $6.1 \%$ samples fall in the high salinity and medium alkali hazard (C3-S2) category, respectively.
Fig. 7 Wilcox diagram demonstrating suitability of water quality for irrigational use

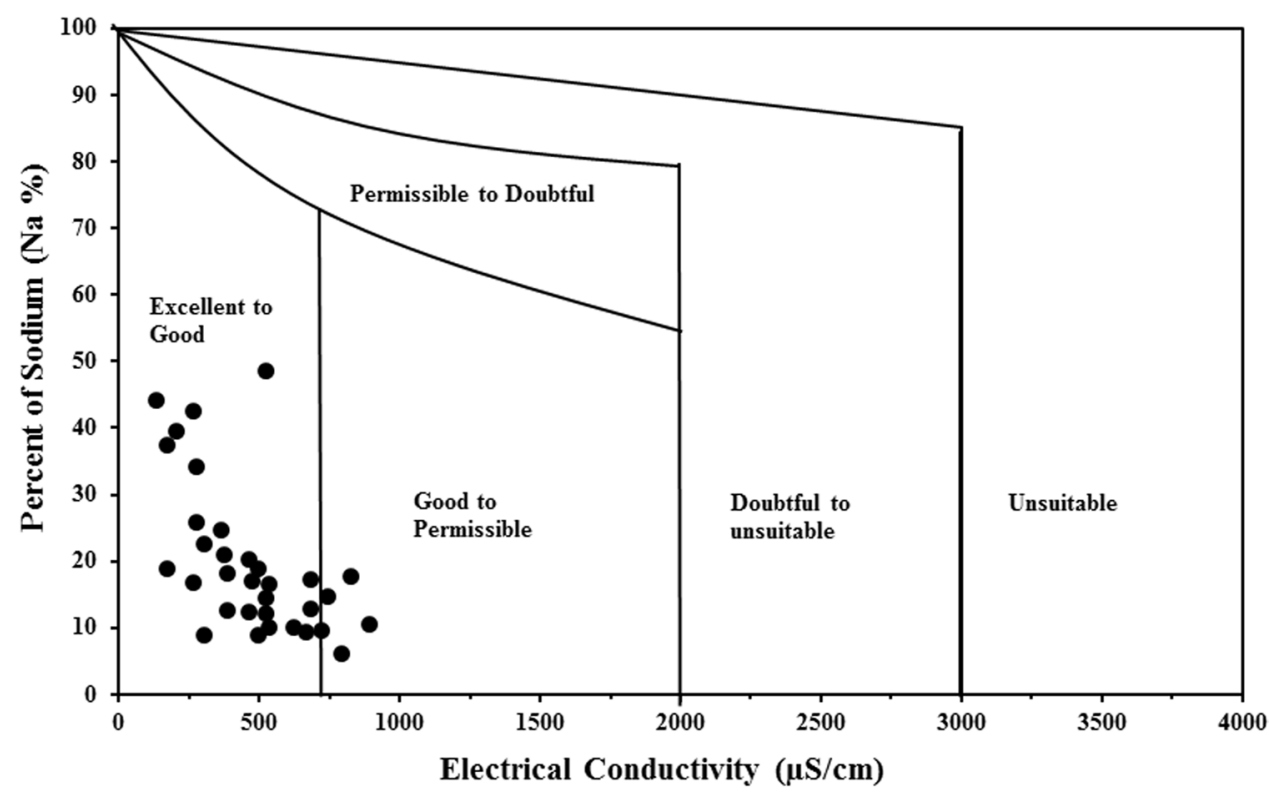


Fig. 8 The USSLS diagram for classification of irrigation water of the study area based on alkali (SAR) and salinity (EC) hazards

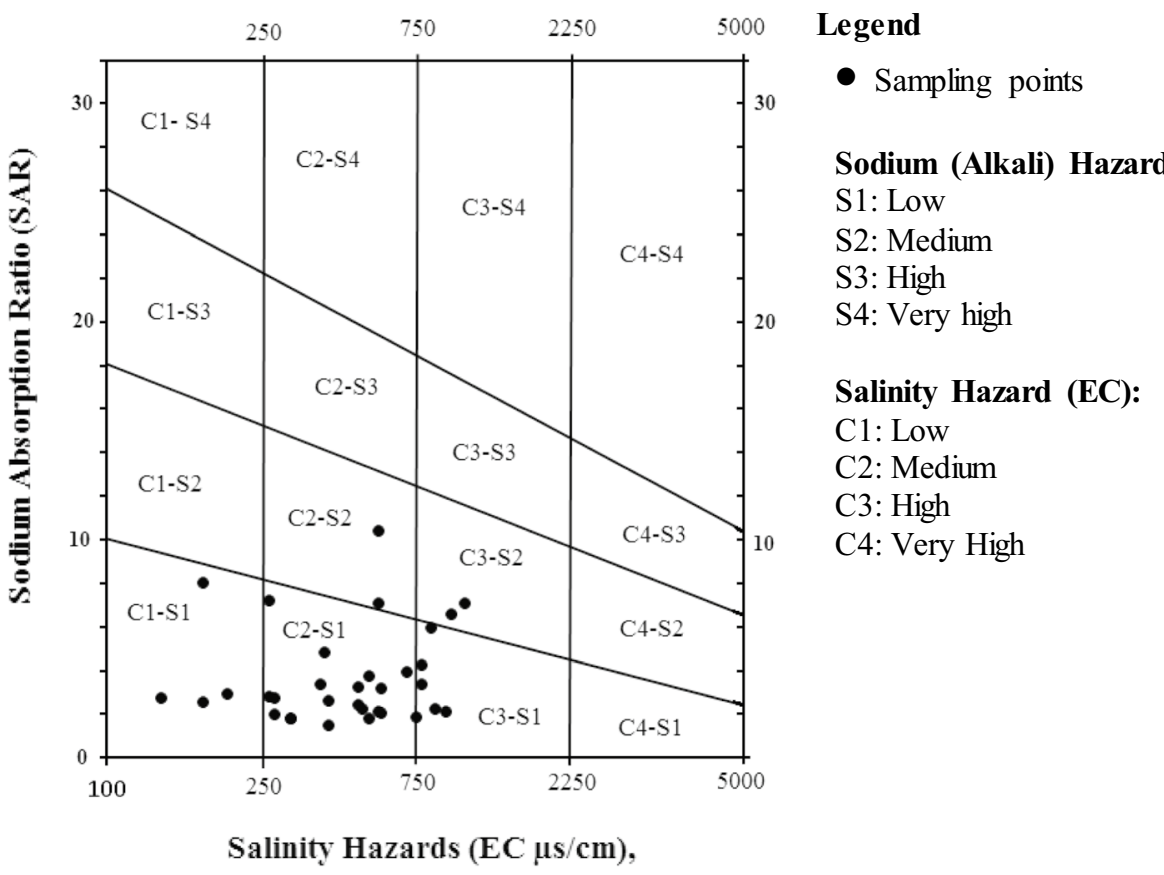

\section{Conclusion}

The present assessment reveals the spatial variability of groundwater quality parameters and hydrogeochemistry of the aquifer formation in the study area. The studies also unveil the presence of geogenic contaminants such as $\mathrm{F}^{-}, \mathrm{Cl}^{-}$and $\mathrm{SO}_{4}{ }^{2-}$ in some of the groundwater samples in exceeding concentration. Groundwater quality is significantly influenced by elevated concentrations of EC, TDS, salinity, $\mathrm{Na}^{+}, \mathrm{Cl}^{-}$and $\mathrm{SO}_{4}{ }^{2-}$ that further impact the overall groundwater quality indices for a few habitations. WQI of the study area was found to be excellent to good except for few habitations where WQI exhibits poor value due to elevated concentrations of $\mathrm{F}^{-}, \mathrm{Cl}^{-}, \mathrm{EC}$, salinity, TDS, $\mathrm{SO}_{4}{ }^{2-}$ and $\mathrm{PO}_{4}{ }^{3-}$. The fluoride concentration in few samples exceeds permissible limit of WHO, which highlights the possibility of public health impacts. The predicted geospatial distribution maps of WQI and fluoride concentration indicate the presence of possible pockets of $\mathrm{F}^{-}$contaminated aquifer in the habitations. The major hydrogeochemical classification indicates $\mathrm{Na}^{+}-\mathrm{Ca}^{2+}-\mathrm{Mg}^{2+}-\mathrm{Cl}^{-}-\mathrm{HCO}_{3}{ }^{-} \mathrm{SO}_{4}{ }^{2-}$ type of water, and the major ion chemistry is dominated by rock weathering and silicate weathering process. The five principal components account for $83.0 \%$ variances in the hydrogeochemical variables of the study area. The PCA identifies the nature of variations in hydrogeochemical interactions and underlying geochemical processes that are highly correlated with EC, salinity, TDS, $\mathrm{Cl}^{-}, \mathrm{Na}^{+}$, $\mathrm{SO}_{4}{ }^{2-}$ and $\mathrm{PO}_{4}{ }^{3-}$. The irrigational water quality of majority of groundwater samples was found to be in acceptable range except for few samples where high salinity (EC) and alkali (sodium) hazards were witnessed due to elevated concentration of alkali metal ions and halite-dominated salts.

Acknowledgements The authors acknowledge the Department of Earth Science, Manipur University, for allowing to use facilities of ArcGIS software for the preparation of geospatial distribution maps. Moreover, the authors acknowledge ICAR-KVK Chandel, Manipur, for their valuable support for timely collection of water samples and their logistic.

\section{Compliance with ethical statements}

Conflict of interest The authors declare that they have no conflict of interest.

Open Access This article is licensed under a Creative Commons Attribution 4.0 International License, which permits use, sharing, adaptation, distribution and reproduction in any medium or format, as long as you give appropriate credit to the original author(s) and the source, provide a link to the Creative Commons licence, and indicate if changes were made. The images or other third party material in this article are included in the article's Creative Commons licence, unless indicated otherwise in a credit line to the material. If material is not included in the article's Creative Commons licence and your intended use is not permitted by statutory regulation or exceeds the permitted use, you will need to obtain permission directly from the copyright holder. To view a copy of this licence, visit http://creativecommons.org/licenses/by/4.0/.

\section{References}

Alam W, Yumnam G (2017) Hydrogeochemical assessment of groundwater resources of Imphal city. J Ind Water Works Assoc 39(3):197-204

Alam W, Gyanendra Y, Neihsial MT, Nesa N (2019) Hydrogeochemical assessment of groundwater arsenic and fluoride contamination in Thoubal district, Manipur, India. J Earth Sci India 12(1):38-52 
APHA (2005) Standard methods for the examination of water and wastewater, 21st edn. America Public Health Association, Washington, DC

Batabyal AK, Chakraborty S (2015) Hydrogeochemistry and water quality index in the assessment of groundwater quality for drinking uses. Water Environ Res 87(7):607-617

Bhattacharya P, Sracek O, Eldvall B, Asklund R, Barmen G, Jacks G, Koku J, Gustafson JE, Singh N, Balfors BB (2012) Hydrogeochemical study on the contamination of water resources in a part of Tarkwa mining area, Western Ghana. J Afr Earth Sci 66-67:72-84

Bouwer H (1978) Groundwater hydrology. McGraw-Hill, New York, p 480

Briggs JC, Ficke JF (1977) Quality of rivers of the United States, 1975 water year based on the National Stream Quality Accounting Network (NASQAN), USA

Census (2011) District Census Handbook, Bishnupur, Census of India, Series 15, Part XII-B, Directorate of Census Operation, Government of Manipur

Central Groundwater Board (CGWB) (2013) Ground water information booklet of Chandel district, Manipur, Technical Report Series: D, No: 10/2013-14, Central Groundwater Board, North Eastern Region, Ministry of Water Resources. Govt. of India, New Delhi

Chakraborty D, Singh J, Das B, Shah BA, Hossain AM, Nayak B, Ahamed S, Singh R (2008) Groundwater arsenic contamination in Manipur, one of the seven North-Eastern hill states of India: a future danger. Environ Geol 56(2):381-390

Choudhury R, Mahanta C, Borah PJ, Saikia Land Alam W (2011) Screening of groundwater arsenic contamination in unexplored parts of Brahmaputra floodplains in Assam. In: Proceedings of the conference on Arsenic in Groundwater in southern Asia, 2011, Hanoi, Vietnam

Devi OJ, Ramanathan AL, Singh G (2012) Geochemical and statistical evaluation of groundwater in Imphal and Thoubal district of Manipur, India. J Asian Earth Sci 48:136-149

Doneen ID (1964) Notes on water quality in agriculture, published as water science and engineering paper 4001, Department of Water Sciences and Engineering, University of California

Drever JJ (1997) The geochemistry of natural water, 3rd edn. PrenticeHall, Upper Saddle River, p 338

Eaton FM (1950) Significance of carbonate in irrigation water. Soil Sci 69:123-133

Freeze RA, Cherry JA (1979) Groundwater. Englewood Cliffs, Prentice-Hall, p 604

Gibbs RJ (1970) Mechanism controlling world water chemistry. Science 170:1088-1090

Hameed A, Alobaidy MJ, Abid HS, Mauloom BK (2010) Application of water quality index for assessment of Dodkan lake ecosystem, Kurdistan region, Iraq. J Water Resour Prot 2:792-798

Kresic N (1997) Hydrogeology and groundwater modeling. Lewis Publishers, New York, p 35

Kumar M, Kumari K, Singh UK, Ramanathan AL (2009) Hydrogeochemical processes in the groundwater environment of Muktsar, Punjab: conventional graphical and multivariate statistical approach. Environ Geol 57:873-884

Mahanta C, Pathak N, Choudhury R, Borah P, Alam W (2009) Quantifying the spread of arsenic contamination in groundwater of the Brahmaputra floodplains, Assam, India: a threat to public health of the region, Great Rivers. In: Proceedings of the World
Environmental and Water Resources Congress 2009, ASCE, Kansas City, Missouri, USA

Mahanta C, Choudhury R, Basu S, Hemani R, Dutta A, Barua PP, Borah PJ, Bhattacharya M, Bhattacharya K, Alam W, Saikia L, Mukherjee A, Bhattacharya P (2015) Preliminary assessment of arsenic distribution in Brahmaputra river basin of India based examination of 56180 public groundwater wells; safe and sustainable use of arsenic-contaminated aquifers in the gangetic plain. Springer, USA, pp 57-64

Manipur State Action Plan for Climate Change (MSAPCC) (2015) Directorate of Environment. Govt. of Manipur, India

McSween HY, Uhle M, Richardson SM (2003) Geochemistry: pathways and processes, 2nd edn. Colombia University Press, USA

Mukherjee A, Fryar AE, Scanlon BR, Bhattacharya P, Bhattacharya A (2011) Elevated arsenic in deeper groundwater of western Bengal basin, India: extents and controls from regional to local-scale. Appl Geochem 26:600-613

Mukherjee A, Saha D, Harvey CF, Taylor RG, Ahmed KM, Bhanja SN (2015) Groundwater systems of the Indian sub-continents. J Hydrol Regional Stud 4(A):1-14

O'Geen A (2015) Drought tip: Reclaiming saline, sodic, and salinesodic soils, Agriculture and Natural Resources Publication 8519, University of California

Piper AM (1953) A graphic procedure in the geochemical interpretation of water analysis. United States Geological Survey, Washington, DC

Prusty P, Farooq SH, Zimik HV, Barik SS (2018) Assessment of the factors controlling groundwater quality in a coastal aquifer adjacent to the Bay of Bengal, India. Environ Earth Sci 77:762

Ramakrishnaiah CR, Sadashivaiah C, Ranganna G (2009) Assessment of water quality index for the groundwater in TumkurTaluk, Karnataka state, India. J Chem 7:428-432

Richards LA (1954) Diagnosis and improvement of saline and alkali soils. Agriculture Handbook, US Salinity Laboratory, Department of Agriculture, Washington, DC, p 60

Singh SN, Singh AN, Singh TK, Singh TR (2013) Thermoluminescence of natural salt extracted from the saline spring of Ningel, Manipur. Int J Lumin Appl 3(1):49-51

Todd DK (2003) Groundwater hydrology, 2nd edn. Wiley, New York, p 535

United States Salinity Laboratory Staff (USSLS) (1954) Diagnosis and improvement of saline and alkaline soils. Agriculture Handbook, US Department of Agriculture, Washington, DC

Verma S, Mukherjee A, Choudhury R, Mahanta C (2015) Brahmaputra river basin groundwater: solute distribution, chemical evaluation and arsenic occurrences in different geomorphic settings. J Hydrol Reg Stud 4(A):131-153

Wilcox LV (1955) Classification and use of irrigation Water, US Department of Agriculture, Circular 969, Washington, DC, p 19

World Health Organisation (WHO) (2011) Guidelines for drinking water quality, 4th ed. World Health Organization (WHO), Geneva, pp 224-334

Publisher's Note Springer Nature remains neutral with regard to jurisdictional claims in published maps and institutional affiliations. 